\title{
Laparoscopic Total Extraperitoneal Inguinal Hernia Repair Without Mesh Fixation: Report of Early Outcomes
}

\author{
Julide Sağıroğlu, Tuğrul Özdemir, Tuba Atak, Mehmet Ali Gök, \\ Kıvılcım Orhun Erdoğan, Tunç Eren, Orhan Alimoğlu
}

Department of General Surgery Istanbul Medeniyet University Faculty of Medicine, Göztepe Training and Research Hospital, İstanbul, Turkey

Submitted: 21.09 .2015 Accepted: 14.12 .2015

Correspondence: Julide Sağıroğlu, İstanbul Medeniyet Üniv., Göztepe

Eğitim ve Araş. Hastanesi, Genel Cerrahi Kliniği, İstanbul, Turkey E-mail: sagirj@gmail.com

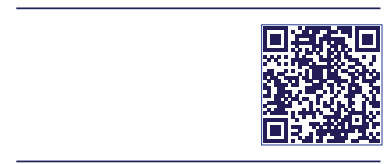

Keywords: Inguinal hernia; laparoscopic TEP repair; non-fixation.

\begin{abstract}
Objective: This report is an analysis of outcomes of laparoscopic total extraperitoneal (TEP) inguinal hernia repair without using mesh fixation.

Methods: Hospital records of 60 patients who underwent laparoscopic TEP inguinal hernia repair between 2012 and 2015 in the clinic were retrospectively analyzed for length of operative time, postoperative pain, paresthesia, urinary retention, seroma, hematoma, infection, recurrence, and chronic pain.
\end{abstract}

Results: Three of 60 study patients were female (5\%), 57 were male (95\%); mean age was 48 years (range: $27-66$ years). Five (8\%) patients presented with recurrent inguinal hernia, $50(83 \%)$ with unilateral, and $5(8 \%)$ with bilateral inguinal hernia. Conversion to open hernia repair technique was recorded in 4 cases. At $24^{\text {th }}$ postsurgical hour, all patients described level I-2 pain at incision site. Only 4 patients had level 2 pain at the end of the first week, and none complained of pain at first, third, and sixth month of follow-up period. Paresthesia was recorded in 6 patients during the entire follow-up period. Seroma, which was prominent in 4 patients during first postoperative week, subsided by first month follow-up. None of the patients had hematoma, urinary retention, infection, recurrence, or chronic pain.

Conclusion: Laparoscopic TEP inguinal hernia repair without mesh fixation is a safe technique when performed by experienced surgeons.

\section{INTRODUCTION}

One of the most frequently performed operations in the practice of general surgery is inguinal hernia repair. Multiple surgical techniques have been described, and for years, tension repair techniques such as the Bassini and Shouldice methods have been used.

Since the end of 1980s, the Lichtenstein method, which uses prosthetic material, was accepted as optimal method of inguinal hernia repair. In recent years, however, minimally invasive methods such as transabdominal preperitoneal (TAPP) and total extraperitoneal (TEP) approaches have been used for inguinal hernia repair. ${ }^{[1]}$ Although both of these methods are effective, TEP is becoming more popular among surgeons. Giant scrotal hernia and presence of an incision in the lower abdominal quadrant are contraindications.

Placement of the mesh is the most frequently debated issue of TEP operation. A wide spectrum of methods have been described in the literature, ranging from nonfixation methods of placement to fixation with metal tacks. ${ }^{[2-5]}$ Much of the debate concerns chronic postoperative pain and recurrence. Lichtenstein method and TEP have been compared in various studies, and while a relatively lower incidence of recurrence and chronic pain has been recorded for TEP, both complications can still occur.

Though chronic pain has many etiologies, the method of fixation can be a cause. Use of absorbable tacks 
and tissue adhesives such as fibrin glue or cyanoacrylate have been described in numerous literature studies. ${ }^{[6,7]}$ In some investigations, less chronic pain has been reported for hernia repairs that did not use tacks; however, in general, there is not much difference between methods. Therefore, this decision should be left to the discretion of the surgeon.

No definitive advantage for fixation of mesh has been proven, other than in instances of large inguinal defects or inadequate mesh. It has been suggested that many fixation-related morbidities, including chronic pain, recurrence, prolonged operative time, and increased cost can be avoided using nonfixation method. ${ }^{[5,8,9]}$

The present study is an analysis of the outcomes of laparoscopic TEP herniorrhaphy without mesh fixation.

\section{PATIENTS AND METHODS}

Records of 60 patients who underwent TEP herniorrhaphy between September 2012 and July 2015 were evaluated retrospectively with respect to operative time, postoperative pain, paresthesia, urinary retention, seroma, hematoma, infection, recurrence, and chronic pain. Patients who had previously undergone open or laparoscopic lower abdominal surgery, who were given American Society of Anesthesiologists (ASA) Class 4 or 5 rating, and those with diagnosis of femoral hernia for whom general anesthesia was contraindicated were not included in the study. All TEP hernia repairs were performed under general anesthesia by the same surgical team. All patients received single intravenous dose of I g cephalosporin 30 minutes before the operation. Parameters were recorded at 24 hours, I week, and I, 3, and 6 months after surgery. Severity of pain was rated as follows: level I=no pain, 2=mild pain, 3=moderate pain, 4=severe pain, and $5=$ intolerable pain. Demographic data of the patients, ASA classification, characteristics of the hernia, operative time, reason for switching to open surgery (if applicable), severity of any peritoneal damage, complications seen during first postoperative month, and length of hospital stay were recorded. Operative time was evaluated as the time elapsed between first incision and last suturing. Chronic pain was defined as level 4 pain occurring 3 months after the operation. Intraoperative complications (e.g., epigastric or testicular vascular bleeding, peritoneal, testicular, or nerve damage) and postoperative complications (e.g., hematoma, seroma, urinary retention, paresthesia, wound infection, and recurrence) were recorded.

Surgical technique: Urinary catheterization was performed for all patients prior to surgery and all received prophylactic I g cephalosporin intravenously 30 minutes before the operation. Under general anesthesia, inguinal hernia was exposed through infraumbilical incision and anterior sheath of ipsilateral rectus muscle was opened. Without opening posterior sheath of rectus muscle, a space was created under the sheath with blunt dissection, and the tunnel was extended to pubic symphysis. Balloon trocar was not used; $10 \mathrm{~mm}$ trocar was inserted through infraumbilical incision into retrorectal region, and carbon dioxide insufflation was performed at fixed pressure of $8-10 \mathrm{mmHg}$. Probe of 0 degree optic camera was inserted through incision, and blunt dissection was maintained. Pubic symphysis and inferior epigastric arteries were clearly visualized, and 2 trocars each with a diameter of $5 \mathrm{~mm}$ were placed inside preperitoneal space between umbilicus and pubic symphysis at $5 \mathrm{~cm}$ intervals. Peritoneal layer that constituted hernia sac was liberated with lateral or medial dissection according to characteristics of indirect or direct hernia. Any peritoneal defect observed was sutured or clipped. Polypropylene mesh (Prolene; Ethicon, Inc., Somerville, NJ, USA) 10 to $15 \mathrm{~cm}$ in length was placed on musculopectineal orifice, also covering medial and lateral borders of the defect. Mesh was not fixed to any anatomical structure. Following a final inspection, desufflation was performed and trocars were removed. Infraumbilical incision was closed with fascia suture using standard methods. Lichtenstein hernia repair was employed in cases that were converted to open surgery.

\section{RESULTS}

Three female (5\%) and 57 (95\%) male patients with an overall mean age of 48 years (range: $27-66$ years) were included in the study. Recurrent hernia $(n=5$; $8.3 \%)$, unilateral $(n=50 ; 83.4 \%)$, and bilateral hernias $(n=5 ; 8.3 \%)$ were detected (Table I). In 4 (6.6\%) patients, change to open surgery was required because of technical problems. Unilateral hernias were leftsided in 32 cases and right-sided in 18. Laparoscopic procedures were completed in an average of 62 minutes (range: 35-1 I8 minutes). All patients were discharged at the end of first postoperative day. At postoperative 24 hours, level I-2 pain was observed 
Table 1. Demographic characteristics

\begin{tabular}{lc}
\hline Total number of hernias & 60 \\
Unilateral inguinal hernias (\%) & 83 \\
Bilateral inguinal hernias (\%) & 8 \\
Recurrent inguinal hernias (\%) & 8 \\
Mean age (years) & 48 (range: 27-66) \\
Female/male & $3 / 57$ \\
\hline
\end{tabular}

in all patients. At first postoperative week, level 2 pain was noted in 4 patients. At I, 3, and 6-month follow-up, all patients were completely pain-free. At sixth month, 6 patients were paresthesic. Seroma, which was seen at first postoperative week in 4 patients, had dissipated at postoperative first month follow-up. No patient experienced hematoma, urinary retention, infection, or recurrence (Table 2 ).

\section{DISCUSSION}

Many studies have demonstrated that nonfixation method of laparoscopic TEP hernia repair can be used safely. ${ }^{[2]}$ Concerns about recurrence rates of inguinal hernia when repaired without mesh fixation led to investigation and documentation of differences in short- and long-term outcomes in patient groups from many perspectives. ${ }^{[2-5]}$ In the TEP method, stabilization of the nonfixated mesh placed between anterior wall of the abdomen and peritoneum is based on sandwich effect created between tissues. In order to reinforce this sandwich effect, the lower $2-3 \mathrm{~cm}$ part of the prosthetic mesh is placed in the Retzius cavity, where it is held in place after completion of desufflation. Choy et al. performed preperitoneal relaparoscopy and demonstrated that mesh stabilized using this method did not change position with hip flexion. ${ }^{[10]}$ Postoperative X-ray studies conducted by Irving et al. also showed no movement in mesh stabilized using this method. ${ }^{[1]}$ Within the first postoperative 2 weeks, mesenchymal cells proliferate in the mesh, and within the first 2 months, tissue is incorporated into the mesh and adequate amount of collagen develops. ${ }^{[12]}$ Accumulation of collagen strengthens permanent stabilization of mesh in the preperitoneal area. For early fixation sandwich effect, and for long-term mesh stabilization and permanent fixation, tissue incorporation is necessary.

Garg et al. performed a prospective study in 104 patients from rural area of Southern India and compared the outcomes of patients who had undergone laparoscopic TEP surgery with mesh fixation to nonfixation methods. At the end of at least 2 years of postoperative follow-up, they could not demonstrate any significant difference between groups as far as postoperative pain, duration of hospital stay, return to normal daily activities, seroma formation, or recurrence. ${ }^{[2]}$

Laparoscopic TEP hernia repair has generally been reported to result in fewer problems than open herniorrhaphy, but nearly one-fifth of patients still described a new type of groin pain. ${ }^{[8]}$ Chronic pain develops in $5-35 \%$ of adults who have inguinal hernia repair. Noting that this type of pain can develop as a result of surgical technique used, pre- and postoperative pain, psychosocial and physiological characteristics of the patient, and other factors, the authors of another study indicated that they couldn't arrive at a final consensus as to cause of chronic postoperative pain. ${ }^{[13]}$ While many authors have reported that type of hernia does not influence prevalence of chronic

Table 2. Short- and long-term complications

\begin{tabular}{lccccc}
\hline & $24 \mathrm{hrs}$ & $1 \mathrm{wk}$ & $1 \mathrm{mo}$ & $3 \mathrm{mo}$ & $6 \mathrm{mo}$ \\
\hline Postoperative pain (short-term) & All patients & 4 & 0 & 0 & 0 \\
Chronic pain & - & - & - & 0 & 0 \\
Paresthesia & 6 & 12 & 12 & 8 & 6 \\
Seroma & 0 & 4 & 0 & 0 & 0 \\
Hematoma & 0 & 0 & 0 & 0 & 0 \\
Urinary retention & 0 & 0 & 0 & 0 & 0 \\
Infection & 0 & 0 & 0 & 0 & 0 \\
Recurrence & 0 & 0 & 0 & 0 & 0 \\
\hline
\end{tabular}


pain, the critical role of recurrent hernia repair on the development of chronic pain is still debated. ${ }^{[14]}$ Metal clips or tacks used in the fixation of mesh have been held responsible for this type of pain, and a series of techniques other than using tacks, including fibrin glue, cyanoacrylate, and absorbable sutures have been used to prevent development of pain. ${ }^{[6,7]}$ In the current study, there were fewer recurrent hernias than primary hernias, yet chronic pain did not develop in any of our patients.

In the present study, mesh fixation was not performed during laparoscopic TEP procedure to avoid potential nerve damage and related chronic pain. When groups who underwent mesh fixation and nonfixation were compared at the end of 12 months of follow-up, no significant difference was detected between groups regarding recurrence or return to normal activities. The superiority of nonfixation method in terms of avoiding potential nerve damage as well as limiting surgical expenses has been acknowledged. ${ }^{[9,15]}$ Lau et al. used fixation method for hernias with a diameter larger than $4 \mathrm{~cm}$ where mesh failed to cover hernial defect completely, and found no significant difference when compared to nonfixation method in terms of length of hospital stay, return to normal daily activities, or postoperative morbidity. ${ }^{[16]}$ In their laparoscopic TEP hernia repair study of $\mathbf{I 7 2}$ cases, Khajanchee et al. evaluated outcomes of use of fixation in 67 cases and no fixation in 105. They concluded development of complications of neuralgia and paresthesia was greater in patients who had undergone mesh fixation procedure, which they attributed to inflammatory effect of tacks. ${ }^{[17]}$ In another TEP study of 89 cases, Beattie et al., who advocated nonfixation method, did not apply mesh fixation in any of their patients, but spread the mesh only on spermatic cord in I group. In the other group, they divided mesh in half vertically, wrapped each half around spermatic cord structures, and recorded outcomes of a median postoperative follow-up period of 33 months. ${ }^{[18]}$ They did not observe any intergroup difference in postoperative morbidity, and they didn't encounter any instance of recurrence. Claus et al. investigated mesh migration in laparoscopic TEP hernia repair and compared results of radiological examinations performed immediately, and 30 days after surgery in groups that underwent hernia repair with or without mesh fixation, and also reported lack of any difference between groups. ${ }^{[19]}$
In their meta-analysis, Tam et al. reported that hernia repair using TEP laparoscopic method without mesh fixation could significantly decrease operative time, surgical costs, and length of hospital stay, and they found no difference between mesh fixation and nonfixation methods in terms of hernia recurrence, complications, or postoperative pain. ${ }^{[20]}$ In another meta-analysis performed by Sajid et al., authors indicated that laparoscopic nonfixation TEP method did not increase recurrence risk, and indicated that operative time, postoperative pain, complications, length of hospital stay, and chronic inguinal pain were similar to that detected in cases of mesh fixation method. ${ }^{[21]}$

Limitations of present study include its retrospective design, small number of patients, and short postoperative follow-up period. Results support the abovementioned findings of researchers and demonstrate that laparoscopic TEP inguinal hernia repair performed without mesh fixation is a reliable technique that can reduce postoperative morbidity when applied by adequately experienced surgeons.

Conflict of interest

None declared.

\section{REFERENCES}

1. Dulucq JL. Treatment of inguinal hernia by insertion of a subperitoneal patch under pre-peritoneoscopy. Chirurgie 1992;118:83-5.

2. Garg P, Nair S, Shereef M, Thakur JD, Nain N, Menon GR, Ismail M. Mesh fixation compared to nonfixation in total extraperitoneal inguinal hernia repair: a randomized controlled trial in a rural center in India. Surg Endosc 2011;25:3300-6.

3. Koch CA, Greenlee SM, Larson DR, Harrington JR, Farley DR. Randomized prospective study of totally extraperitoneal inguinal hernia repair: fixation versus no fixation of mesh. JSLS 2006;10:45760 .

4. Parshad R, Kumar R, Hazrah P, Bal S. A randomized comparison of the early outcome of stapled and unstapled techniques of laparoscopic total extraperitoneal inguinal hernia repair. JSLS 2005;9:403-7.

5. Moreno-Egea A, Torralba Martínez JA, Morales Cuenca G, Aguayo Albasini JL. Randomized clinical trial of fixation vs nonfixation of mesh in total extraperitoneal inguinal hernioplasty. Arch Surg 2004;139:1376-9.

6. Kaul A, Hutfless S, Le H, Hamed SA, Tymitz K, Nguyen H, et al. Staple versus fibrin glue fixation in laparoscopic total extraperitoneal repair of inguinal hernia: a systematic review and meta-analysis. Surg Endosc 2012;26:1269-78.

7. Ladwa N, Sajid MS, Sains P, Baig MK. Suture mesh fixation versus glue mesh fixation in open inguinal hernia repair: a systematic review and meta-analysis. Int J Surg 2013;11:128-35.

8. Taylor C, Layani L, Liew V, Ghusn M, Crampton N, White S. Laparoscopic inguinal hernia repair without mesh fixation, early results of a large randomised clinical trial. Surg Endosc 2008;22:757-62.

9. Ferzli GS, Frezza EE, Pecoraro AM Jr, Ahern KD. Prospective randomized study of stapled versus unstapled mesh in a laparoscopic 
preperitoneal inguinal hernia repair. J Am Coll Surg 1999;188:4615.

10. Choy C, Shapiro K, Patel S, Graham A, Ferzli G. Investigating a possible cause of mesh migration during totally extraperitoneal (TEP) repair. Surg Endosc 2004;18:523-5.

11. Irving SO, Deans GT, Sedman PC, Royston CM, Brough WA. Does the mesh move after TAPP hernia repair? An X-ray study. Minimal Invasiv Ther 1995;4:54.

12. Dion YM, Laplante R, Charara J, Marois M. The influence of the number of endoclips and of mesh incorporation on the strength of an experimental hernia patch repair. Surg Endosc 1994;8:1324-8.

13. Kehlet H, Jensen TS, Woolf CJ. Persistent postsurgical pain: risk factors and prevention. Lancet 2006;367:1618-25.

14. Courtney CA, Duffy K, Serpell MG, O'Dwyer PJ. Outcome of patients with severe chronic pain following repair of groin hernia. $\mathrm{Br} \mathrm{J}$ Surg 2002;89:1310-4.

15. Winslow ER, Quasebarth M, Brunt LM. Perioperative outcomes and complications of open vs laparoscopic extraperitoneal inguinal hernia repair in a mature surgical practice. Surg Endosc 2004;18:221-7.

16. Lau H, Patil NG. Selective non-stapling of mesh during unilateral endoscopic total extraperitoneal inguinal hernioplasty: a case-control study. Arch Surg 2003;138:1352-5.

17. Khajanchee YS, Urbach DR, Swanstrom LL, Hansen PD. Outcomes of laparoscopic herniorrhaphy without fixation of mesh to the abdominal wall. Surg Endosc 2001;15:1102-7.

18. Beattie GC, Kumar S, Nixon SJ. Laparoscopic total extraperitoneal hernia repair: mesh fixation is unnecessary. J Laparoendosc Adv Surg Tech A 2000;10:71-3.

19. Claus CM, Rocha GM, Campos AC, Bonin EA, Dimbarre D, Loureiro MP, et al. Prospective, randomized and controlled study of mesh displacement after laparoscopic inguinal repair: fixation versus no fixation of mesh. Surg Endosc 2016;30:1134-40.

20. Tam KW, Liang HH, Chai CY. Outcomes of staple fixation of mesh versus nonfixation in laparoscopic total extraperitoneal inguinal repair: a meta-analysis of randomized controlled trials. World J Surg 2010;34:3065-74.

21. Sajid MS, Ladwa N, Kalra L, Hutson K, Sains P, Baig MK. A metaanalysis examining the use of tacker fixation versus no-fixation of mesh in laparoscopic inguinal hernia repair. Int J Surg 2012;10:22431.

\section{Laparoskopik Total Ekstraperitoneal Kasık Fıtığı Onarımında Tespitsiz Mesh Tekniği: Erken Sonuçlar}

Amaç: Bu araştırmada laparoskopik total ekstraperitoneal (TEP) fıtık onarımında tespitsiz mesh yerleştirme sonuçlarının analizi amaçlandı.

Gereç ve Yöntem: 20I2-20I5 yılları arasında kliniğimizde kasık fıtı̆ı nedeniyle TEP yöntemiyle ameliyat olan 60 hasta ameliyat süresi, ameliyat sonrası ağrı, parestezi, idrar retansiyonu, seroma, hematom, enfeksiyon, nüksetme ve kronik ağrı açısından geriye dönük olarak değerlendirildi.

Bulgular: Altmış olgunun üçü kadın (\%5), 57’si erkek (\%95), yaş ortalaması 48 (dağılım, 27-66 yıl) idi. Beş (\%8) hastada tekrarlayan kasık fıtı̆ı̆, 50 (\%83) hastada tek taraflı, beş (\%8) hastada iki taraflı kasık fıtı̆̆ı mevcuttu. Hastaların dördünde açık fitık tamir yöntemine geçildi. Ameliyattan sonra 24. saat tüm hastalar kesi bölgesinde I-2 seviye arasında ağrı bildirdiler. Sadece dört hasta birinci hafta sonu 2. seviyede ağrı tanımladılar. İzleyen süreçte bir, üç ve altıncı aylarda hastalar ağrı bildirmedi. İzlem süresi boyunca 6 hastada parestezi kaydedildi. Dört hastada ilk hafta görülen seroma birinci ay kontrolünde kaybolmuştu. Hiçbir hastada hematom, üriner retansiyon, enfeksiyon, rekürrens ve kronik ağrı görülmedi.

Sonuç: Mesh tespitsiz laparoskopik TEP kasık fıtı̆̆ı onarımı, tecrübeli cerrahlar tarafından yapıldığında güvenli bir yöntemdir.

Anahtar Sözcükler: Kasık fıtı̆ı̆; laparoskopik TEP onarımı; tespitsiz. 